Jpn. J. Oral Biol., $23: 589-600,1981$.

\title{
ヤツメウナギの口腔粘膜上皮および角質霜表面
}

\author{
におけるマイクロリッジ \\ 上 原 清 子 \\ 福岡歯科大学口腔解部学第一講座 (主任 : 三好作一郎教授)
}

[受付 : 昭和 56 年 7 月 25 日]

\section{Microridges on the oral mucosal epithelium and the horny teeth of the lamprey, Entosphenus japonicus.}

\author{
Kiyoko Uehara \\ The First Department of Oral Anatomy, Fukuoka Dental College, \\ 700 Ooaza-Ta, Nishi-Ku, Fukuoka 814-01 \\ (Chief : Prof. Sakuichiro Miyoshi) \\ [Accepted for publication July 25, 1981]
}

Key words : microridges/oral mucosal epithelium/lamprey/SEM / TEM

\begin{abstract}
The surface cytoarchitectures, named microridges, on the oral mucosal epithelium and horny teeth of the lamprey were investigated by scanning and transmission electron microscopy.

When examined with the scanning electron microscope, most of the microridges on the mucosal epithelium near the pharynx were small knob-like projections. Occasionally, they were short threads composed of a few of these projections. In the center among the horny teeth, the microridges were knob-like projections, gathered and arranged to form a rough hexagonal network. On the mucosal epithelium, a little near the horny teeth, the microridges were thread. like and formed a network. At the base of the horny teeth, the microridges were thread-like and formed a dense network. At the middle of the horny teeth, the microridges were wide and flattened so that the spaces between the ridges appeared to be micropores. At the apex of the horny teeth, the microridges became wider and more thickened and "the micropores" became smaller.
\end{abstract}

A vertical cross section of the mucosal epithelium was examined by transmission electron microscopy. The thread-like microridges were found to be composed of several knob-like projections, or microridges fused together. The knob-like and short thread-like ridges had a few projections on their lateral surfaces. The thread-like ridges that formed the networks had a few knob-like projections on the top surface. The microridges had a glycocarix on the outer leaflet of the plasma membrane, and the cytoplasm contained plenty of filaments.

From these findings, the formation and the function of the microridges were discussed.

\section{緒言}

脊椎動物における重層扁平上皮の自由表面には

福岡市西区大字田 700 ( $\bar{T}$ 814-01)
マイクロリッジと呼ばれる細胞質隆起が存在す る。従来, これは, 切片像のみで観察されていた ため微絨毛として扱われてきた。しかし，走查型 電子顕微鏡の発達に伴ない，この隆起は微䋐毛と 
は異なり, 自由表面で連なり帯状に広がる隆起で, 隆起の描く模様は動物の類および種によって異な ることがわかってきた ${ }^{1-6)}$ 。しかしながら，マイク ロリッジの形成過程や機能についてはまだほとん ど解明されていない年9)。

ヤツメウナギは, 脊椎動物で最も下等とされ, 口腔には重層扁平上皮の一部が角質化してできた 角質歯をもつ ${ }^{10,11)}$ 。そこで，ヤッメウナギの口腔 粘膜上皮と角質歯におけるマイクロリッジの形態 を，主に走査型電子顕微鏡を用いて調べた。得ら れた結果から，マイクロリッジの形成過程および 機能について検討した。

\section{材料と方法}

成育した体長約 $60 \mathrm{~cm}$ のヤツメウナギ，Entosphenus japonicus を材料として使用した。まず, $3 \%$ グルタールアルデヒド $(0.1 \mathrm{M}$ カコジル酸緩 衝液 $\mathrm{pH}$ 7.4) で灌流固定し, 次に切り出した組 織片を同固定液で浸潤固定した。

光学顕微鏡用として, 固定された試料の一部を 水洗, エタノール系列で脱水, セロイジン包埋後, 切片を作成し， ヘマトキシリン・エオシンの重染 色を施した。

走査型電子顕微鏡用として, 試料を緩衝液で洗 い2\%オスミック酸で後固定, エタノール系列で 脱水, 酢酸イソアミルで置換後, 液体二酸化炭素 で臨界点乾燥を行ない，イオンスパッタリング装 置で 金蒸着，JSM-50Aおよび JSM T-20で観察 した。

さらに，透過型電子顕微鏡用としては，試料を 細切し, 緩衝液で洗い $2 \%$ オスミック酸で後固定 し， $2 \%$ 酢酸ウランでブロック染色エタノール系 列で脱水, エポン包埋, 次いで試料を薄切し, 酢 酸ウラン, 酷酸鉛で二重染色した後, JEM-100B で観察した。

\section{所見}

肉眼および光顕観察（図 1，2）

ヤツメウナギの口裂は頭部腹側にあり，口腔は 漏斗状である。口腔内には上口歯, 下口歯, 上唇 歯, 下唇歯, 側歯, 周縁歯と呼ばれる大小 6 種の 角質歯がある。これらは図 2 のごとく粘膜上皮の
一部が角質化してできたものである。上皮は重層 扁平上皮で，咽頭から口唇にむかうにつれて厚く なっている。

\section{走査型電顕観察}

咽頭粘膜上皮から角質歯尖端にかけてマイク口 リッジは次第に変化しており, 咽頭に近い部位, 角質歯に近い部位，角質歯のほぼ三カ所に分けら れる。

\section{1. 咽頭に近い部位の粘膜表面}

咽頭近くにおける上皮の自由表面の大部分は単 突起状のマイクロリッジで覆われている。所々で $2 \sim 3$ コあるいは $5 \sim 6$ コの突起が相連なって帯 状になっている。細胞境界は膨らんで一本の畦の ようになって抢り，その上にも単突起状マイクロ リッジがみられる(図 3 )。前方にゆくにつれてマ イクロリッジは密になる。

\section{2. 角質歯に近い部位の粘膜表面}

角質歯間中央部から角質歯近くにかけて, マイ クロリッジは次のように変化している。上口唇歯 間の中央部の粘膜表面では, マイクロリッジは単 突起状であるが, 密で網目状に集列している（図 4)。角質歯に近づくとマイクロリッジは帯状で, 網目を形成している(図 5)。

さらに，角質歯基底部位近くの上皮は波状の凸 凹が多く見られ，個々の細胞の接合は離れている。 波状の凸部と凹部の粘膜表面ではマイクロリッジ の形態は異なる。凸部では, マイクロリッジは帯 状で, 大小の不規則な粗い網目である。また，先 端から二次突起が数多くでている(図 6,**印)。 凹部では, マイクロリッジは単突起状あるいは短 、帯状で, 疎な部分と密な部分がある（図 $6, *$ 印)。

\section{3. 角質歯表面}

角質歯表面のマイクロリッジは帯状で，網目を 形成している。基部では不定形な網目で, マイク ロリッジ間の空間は広い。所々でマイクロリッジ は膨らんで大きくなり，その空間は狭くなってい る。二次突起は少ないがみられる。細胞境界には 太くて長いマイクロリッジがある(図 7)。先端に むかうにつれてマイクロリッジは幅広く平胆にな っている。したがって, マイクロリッジ間の空間 は狭くなり，微小な穴になっている（図 8一中間 
部, 図 9一先端部)。二次突起は次第に消失し, 先 端部ではみられない。また, 先端部では先端・基底 方向に長いマイクロリッジがみられる（図 $9 \longleftrightarrow$ 印)。細胞境界は中間部では細い溝としてみえ，失 端部では溝は浅くなっている。

\section{透過型電顕観察}

咽頭に近い部位と角質歯間の中央部の自由表面 細胞を縦断した超薄切片像（図10a，b）を観察す ると, 単突起状のもの (図 $10 \mathrm{a}, \mathrm{b} ; \mathrm{P}$ ), 帯状のも の（図10a,b; T) および $2 \sim 3$ の突起が㾑合し 不定形を示すもの（図10a；F）がみられる。単突 起のものと 2,3 の突起が瘉合したものでは側方 に (図10a, b; 矢印), 帯状のものでは自由表面方 向に（図10b; 矢頭）二次突起を出しているもの がある。マイクロリッジおよびその基底部の細胞 質には電子密度の高い微細な 線維が含まれてい る。また, 自由表面における細胞の形質膜には糖 皮がみえる。糖皮はマイクロリッジの先端でよく 発達し線維状に分岐して隣接方向にのびている。

\section{考察}

ヤツメウナギは漏斗状口腔で他魚に吸着し，角 質歯で筋肉を剥ぎとり血液を吸って生活している といわれている。このため, 角質歯先端は摩擦な どの外部からの刺激を最もよく受ける部位であ り，咽頭は食物や水などが流れてゆくところで刺 激をあまり受けない部位である。このことから， 口腔粘膜上皮の咽頭近くから角質歯先端までの自 由表面でのマイクロリッジの形態の変化は，外部 からの刺激の多少に対応しているように思われ る。また，角質歯基底部位近くの粘膜上皮は波状 の凸凹が多く，凸部と凹部とでマイクロリッジの 形態が異なるものも同様に機械的刺激の多少の差 に因ると考えられる。

高木ら $(1976)^{8)}$ は， マイクロリッジの形態を 調 へ，分化過程を第 I 型から第 $\mathrm{V}$ 型の 5 段階に分類 した。ヤッメウナギの口腔粘膜上皮および角質歯 のマイクロリッジの形態は単突起状の第 I 型から

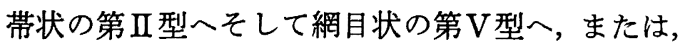
第 I 型から第 $\mathrm{V}$ 型への自由表面上での分化を示し ている。このことは，マイクロリッジの分化が外 部から受ける機械的刺激の量と密接な関係にある
ことを示唆している。単突起状マイクロリッジが どのようにして帯状に移行するかは解明し難い が，側面に突起をもつ単突起状 (図 $10 \mathrm{a}, \mathrm{b}$; 矢印) および 2 のの突起が癒合したようなマイクロリ シジ（図10a； F） はその変化の途上の形態を現わ したもののように思われる。

マイクロリッジは外部からの機械的刺激に対す る防御構造であると考えられるが，超薄切片像に おいてマイクロリッジおよびその基底部には電子 密度の高い微細な線維がつまっている。BerieterHahn (1971) ${ }^{12)}$ はグリセリン処理した後マイクロ リッジがカルシウム依存性の収縮をおこしたと報 告し, また, 龍田, 三枝 (1979) ${ }^{13)}$ はコイの口腔粘 膜においても同様の線維を観察し， サイトカラシ ンBを作用させるとマイクロリッジが消失するこ とを報告した。更に, Berieter-Hahn ら (1979) ${ }^{9}$ ， は螢光抗体法によりマイクロリッジの構成要素は アクチン細糸であろうと報告している。これらの ことは，マイクロリッジ内の線維はアクチン細采 であることおよびマイクロリッジが運動性をもつ 可能性があることを示唆している。更にその他, 著者はムッゴローの歯肉内縁上皮でマイクロリッ ジが歯の植立方向と直角に並行する像 (図11), ア ユの口腔粘膜でマイクロリッジが ロから咽頭方 向, 即ち食物や水の流れに平行する像(図12)，二 イの口腔粘膜でマイクロリッジ間に粘液が保持さ れている像 (図13) を観察した。これらは，マイク ロリッジの機能は機械的刺激に対する補強 (Lanzing and Higginbotham ${ }^{14)} 1974$, Andrews ${ }^{5)}$ 1976), 流れをつくる (Junquerira et al., ${ }^{15)} 1970$ ), 粘液の 保持と拡散 (Hughes and Wright ${ }^{16)} 1970$, Andrews ${ }^{5)} 1976$, Sperry and Wasserung ${ }^{7)} 1976$ ) な どの仮設を支持している。また，マイクロリッジ の表面には厚、糖皮がある。糖皮は細胞種, 細胞 面に依り固有な化学性質をもち, 細胞認識, 細胞 接着，膜の透過性などを荷っているといわれてい る17)。以上のことから，マイクロリッジは機械的 刺激に対する防御構造であるだけではなく，より 能動的な機能をもつと考えられる。

帯状抢よび網目状マイクロリッジから出た自由 表面方向への二次突起は，単突起状マイクロリッ ジが䄖合した時の先端部の残存の様にも考えられ 
るが，透過型電影像（図10b，矢頭）でわかるよう に帯状マイクロリッジから更に突出し，単突起状 のものよりも高く, 癒合時の先端部の残存ではな い。更に, 二次突起および突起の基底部内にはマ イクロリッジ同様, 電子密度の高い微細な線維が 含まれている。これらのことから，この二次突起 はマイクロリッジから出た単突起状マイクロリッ ジであると考えられる。Olson and Formann ${ }^{18)}$ (1973) や Harding ら ${ }^{19)}$ (1974) はマイクロリッ ジはガス交換，物質透過などのために細胞表面を 増加する能率化構造であろうと述べているが， マ イクロリッジから更にマイクロリッジを形成する ことで， 細胞表面は更に増加し，これらの能率を
更によくすると考えられる。

\section{結論}

ヤツメウナギの口腔粘膜上皮の 自由表面に存在 するマイクロリッジを走查型および透過型電子顕 微鏡を用いて観察した。その結果, マイクロリッ ジの構造は，咽頭粘膜上皮から角質歯先端にかけ て単突起状から帯状に，さらに網目状へと連続的 に変化していることがわかった。

\section{謝辞}

本研究の一部は, 文部省科学研究費, 昭和55年度奖励 研究A577035の補助による。

抄録：重層扁平上皮の自由表面には，マイクロリッジと呼ばれる細胞質隆起がある。マイクロリッジの形 成過程および機質について検討するため, ヤッメウナギの口腔粘膜上皮および角質歯の自由表面におけるマ イクロリッジの形態を走查型および透過型電子顕微鏡を用いて観察し，次の結果を得た。1）咽頭近くの粘膜 表面では単突起状マイクロリッジが多く，所々で帯状のものがみられた。前方にゆくにつれて徐々に密にな っていた。2）角膜歯間の中央部の粘膜表面では単突起状マイクロリッジが網目状に集列していた。3）角膜 歯基底部近くの粘膜表面では帯状マイクロリッジが網目を形成していた。4）角質歯表面ではマイクロリッジ は網目状で，先端ほど幅広く平坦になっていた。5）側面および自由表面方向に二次突起をもつマイクロリッ ジがみられた。これらの結果から，形成過程および機能について検討した。

\section{参考文献}

1) Whittaker, D. K. and Adams, D.: The surface layer of human foetal skin and oral mucosa: A study by scanning and transmission electron microscopy. J. Anat., 108 : 453-464, 1971.

2) FAHRENCZY, A. and RICHARD, R. M. : Scanning electron microscopy of the cervical transformation zone. Am. J. Obstet. Cynecol., 115 : 151-157, 1973.

3) Hawkes, J. W.: The structure of skin. General organization. Cell Tiss. Res., 149 : 147-158, 1974.

4) FAHRENBACH, W. H. and KnUtson, D. D.: Surface adaptations of the vertebrate epidermis to friction. J. Invest. Dermatol., $65: 39-44,1975$.

5) ANDRews, P. M.: Micropricae : Characteristic ridge-like folds of the plasmalemma. J. Cell Biol., 68 : 420-429, 1976.

6) ARvidoson, K.: Scanning electron microscopy of fungiform papillae on the tongue of man and monkey. Acta. Otolaryngol., 81 : 496-502, 1976.
7) SPERRY, D. G. and WASSERUnG, R. J.: A proposed function for microridges on epithelial cells. Anat. Rec., $185: 253-258$, 1976.

8) 高木知道, 斎藤 博, 安蘇規子: 微小堤の分化 機構，ヒトの舌の上皮細胞表面形態の走查型電 子顕微鏡による観察. 歯基礎誌, $18: 418-434$, 1976.

9) Bereiter-Hahn, J., Osborn, M., Weber, K. and VoTH, M.: Filament organization and formation of microridges at the surface of fish epidermis. J. Ultrastruct. Res., 69 : 316-330, 1979.

10) GRegory, W. K. : Face from Fish to Man, G. P, Putnams Sons, New York, 1929. 次 記より引用, 三枝 博, 日高秀子, 藤 英俊 : スナヤッメの歯について. 福歯大誌, 4:329336, 1977.

11) Sognaes, R. F. add Lustig, L.: Histochemical reaction of the lamprey mouth. $J$. Dent. Res., 34 : 132-142, 1955.

12) BEREITER-HAHN, J. : Licht-und elektonenmickoskopishe Untersunchungen zur Funktion von Fishen. Cytobiologie, $4: 73-102$, 1971 . 
13）龍田清子, 三枝 博 : 魚類・円口類の口腔粘膜 上皮における microridges の微細構造. 解剖学 雑誌, 54 : 177-178, 1979.

14) LANZING, W. J. R. and HigginbothaM, D. R.: Scanning electron microscopy of surface structure of Tilapia mossambica (Peters) scales. J. Fish Biol., $6: 307-310$, 1974.

15) Junqueria, L. C. U., Tolodo, A. M. S. and PORTER, R. K.: Observation on the structure of the skin of the teleost Fundulus heteroclitus (L). Arch. histo. jap., 32 : 1-15, 1970.

16) Huges, G. M. and Wright D. E.: A comparative study of the water-blood pathway in secondary lamellae of teleost and elasmobranch fishes-benthic forms. Z. Zellforsch., 104 : 478-493, 1970.

17) Cook, G. M. W. and StodarT, R. W. : (監訳者 内海耕慥) 細胞表面の糖質と機能, 追 補版, 257-270, 学会出版センター, 東京, 1978.

18) Olson, K. R. and Fromm, P. O. : A scanning electron microscopic study of secondary lamellae and chloride cells of rainbow trout (Salmo garidnei). Z. Zellforsch., 143 : 439-449, 1973.

19) HARding, C. V., BAGCHi, M., Weinsieder, A. and PETER, V.: A comparative study of coeneal epithelial cell surface ultizing the scanning electron microscope. Invest. Ophthalmol., 13 : 906-912, 1974. 


\section{Exaplanation of Figures}

Fig. 1, 3-9, 11-13 Scanning electron microscopy

Fig. 2 Light microscopy

Fig. 10 Transmission electron microscopy

Fig. 1 A part of the lamprey mouth. The marginal teeth(MT) and the upper labial teeth(UT) are seen. They are appear to put out of the oral mucosal epithelium (Epi). $\times 45$

Fig. 2 Vertical section of the oral mucosal epithelium (Epi) and the horny tooth(T). The horny teeth have the represent horny caps. This horny teeth has the primary ( $\mathrm{HC} 1)$ and the secondary (HC2) horny caps. P : connective tissue papilla. Stained by Hemotoxyline and Eosin. $\times 65$

Fig. 3 Free surface of the mucosal epithelium near the pharynx. Occasionally, the short threads are seen (arrow). The cell boundaries (CB) are swollen. $\times 3,200$

Fig. 4 Free surface of the mucosal epithelium on the center among the horny teeth. The cell boundaries $(\mathrm{CB})$ are swallen. $\times 3,700$

Fig. 5 Free surface of the mucosal epithelium a little far the center among the horny teeth. $\times 3,700$

Fig. 6 Free surface of the mucosal epithelium a little near the horny teeth. The mucosa in this place has crests $(* *)$ and toroughs $(*)$. Several knob-like forms are seen on the top of the microridges (arrow). $\times 2,500$

Fig. 7 Free surface of the base of the horny teeth. Occasionally, the microridges are thickened, and the spaces between ridges are narrow (large arrow). Several knob-like forms are seen on the top of the microridges (small arrow). A long and wide microridges are seen on the cell boundaries (CB). $\times 6,200$

Fig. 8 Free surface of the middle of the horny teeth. The cell bouudaries (CB) are thin grooves. $\times 6,200$

Fig. 9 Free surface of the apex of the horny teeth. Occasinally, the microridges are oriented vertically $(\longleftrightarrow)$. The cell boundaries $(\mathrm{CB})$ are thin shallow grooves. $\times 6,200$

Fig. 10 Vertical cross section of the mucosal epithelium near the pharynx (Fig. 10a) and the center among the horny teeth (Fig. 10b). The knob-like (P), thread-like $(\mathrm{T})$ and fused (F) microridges are seen. The knob-like and fused ridges have a few projections on their lateral surface (arrow). The thread-like ridges have a few knob-like projections on the top surface (arrow head). Fig. 10a. $\times 14,100$, Fig. 10b. $\times 16,300$

Fig. 11 Vertical cut surface of the tootn $(T)$ and the gum (Epi) of the gobby. The microridges $(\mathrm{Mr})$ run perpendicularly to the tooth standing. $\times 1,800$

Fig. 12 Free surface of the pharynx of the young Ayu. The microridges (Mr) run paralle to the line of the mouth and the pharynx. $\times 2,000$

Fig. 13 Free surface of the oral mucosa of the carp. The mucus droplets (M) anchor on the microridges $(\mathrm{Mr}) . \times 4,900$ 
上原清子：ヤッメウナギの口腔表面におけるマイクロリッジ
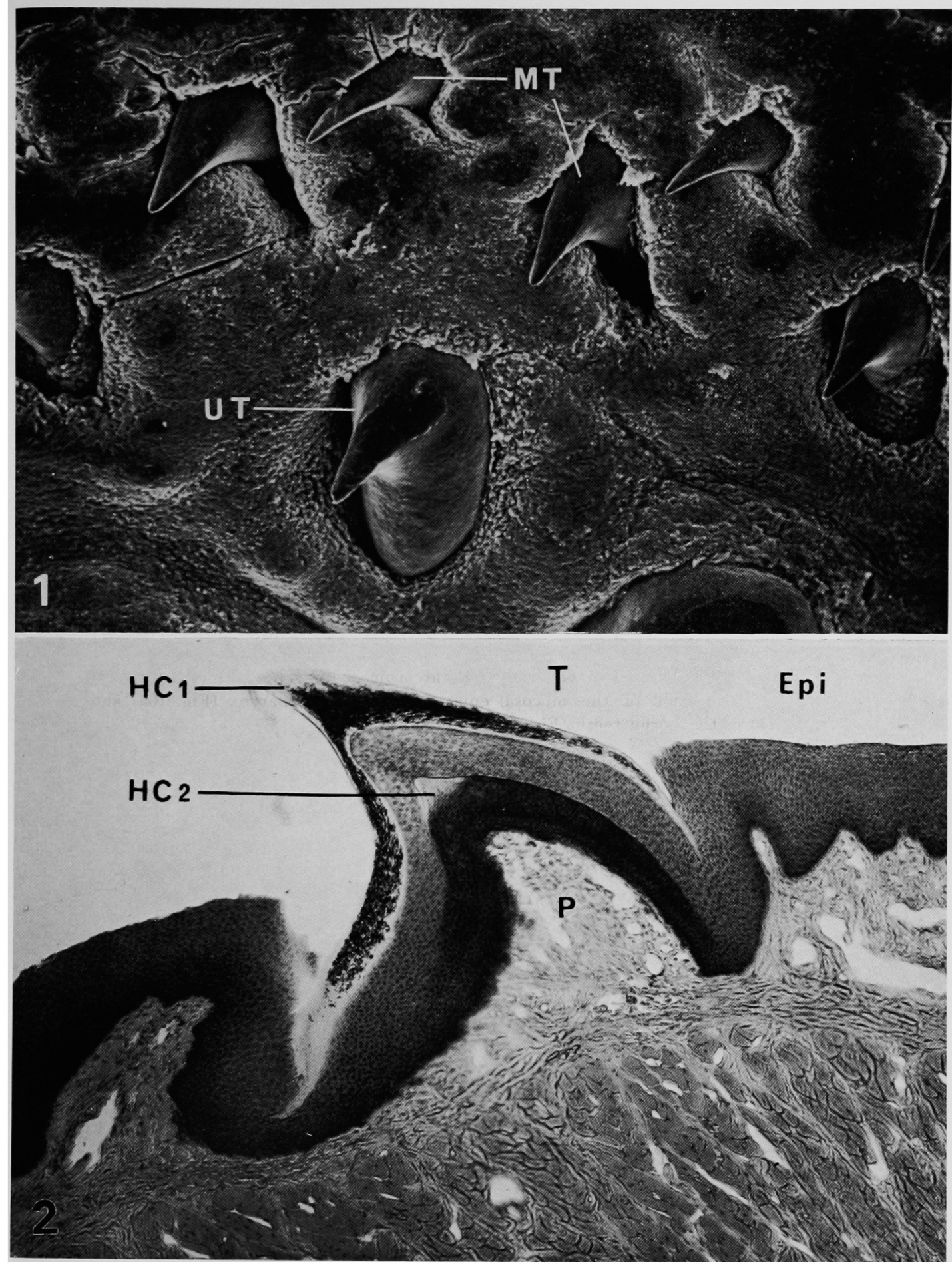


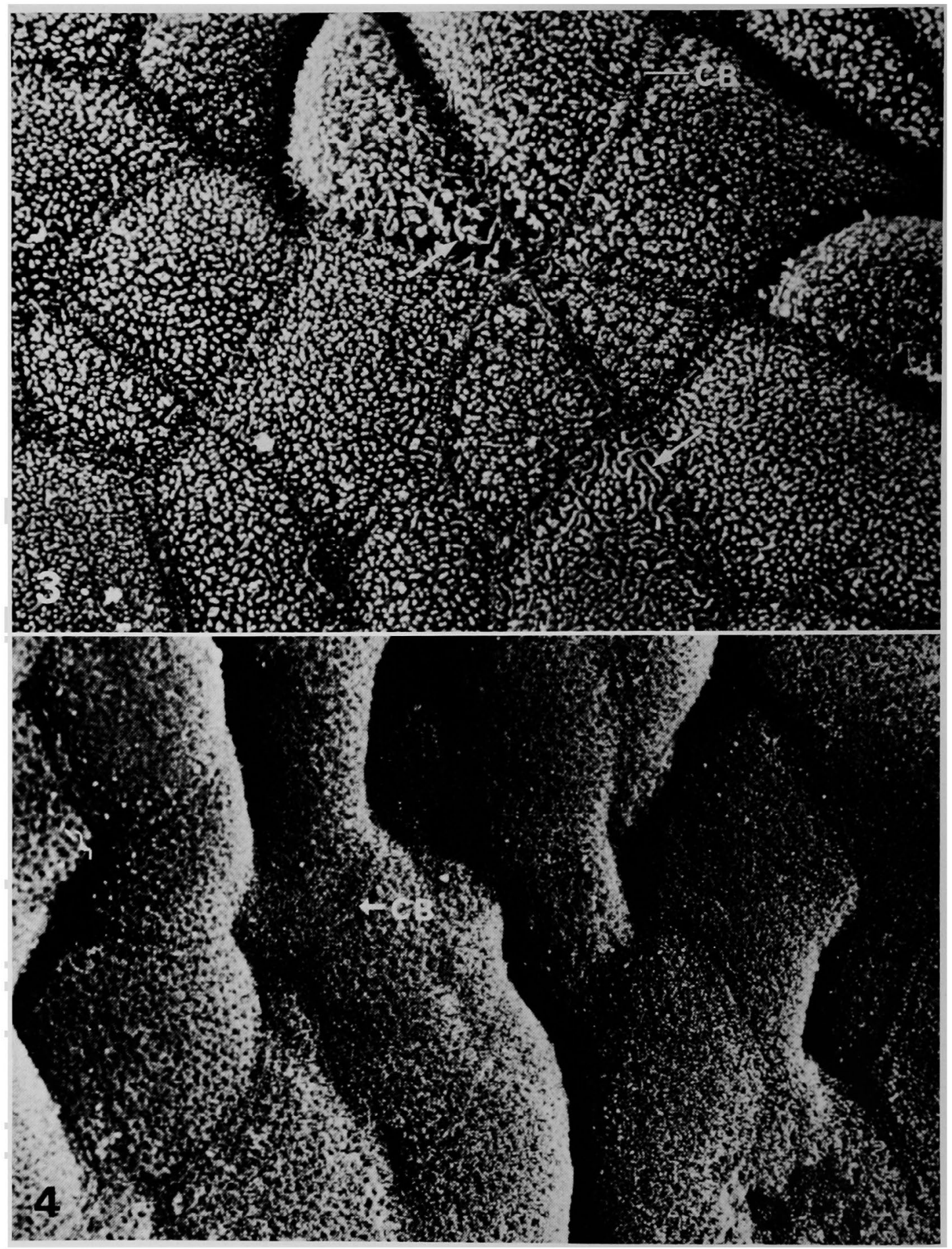




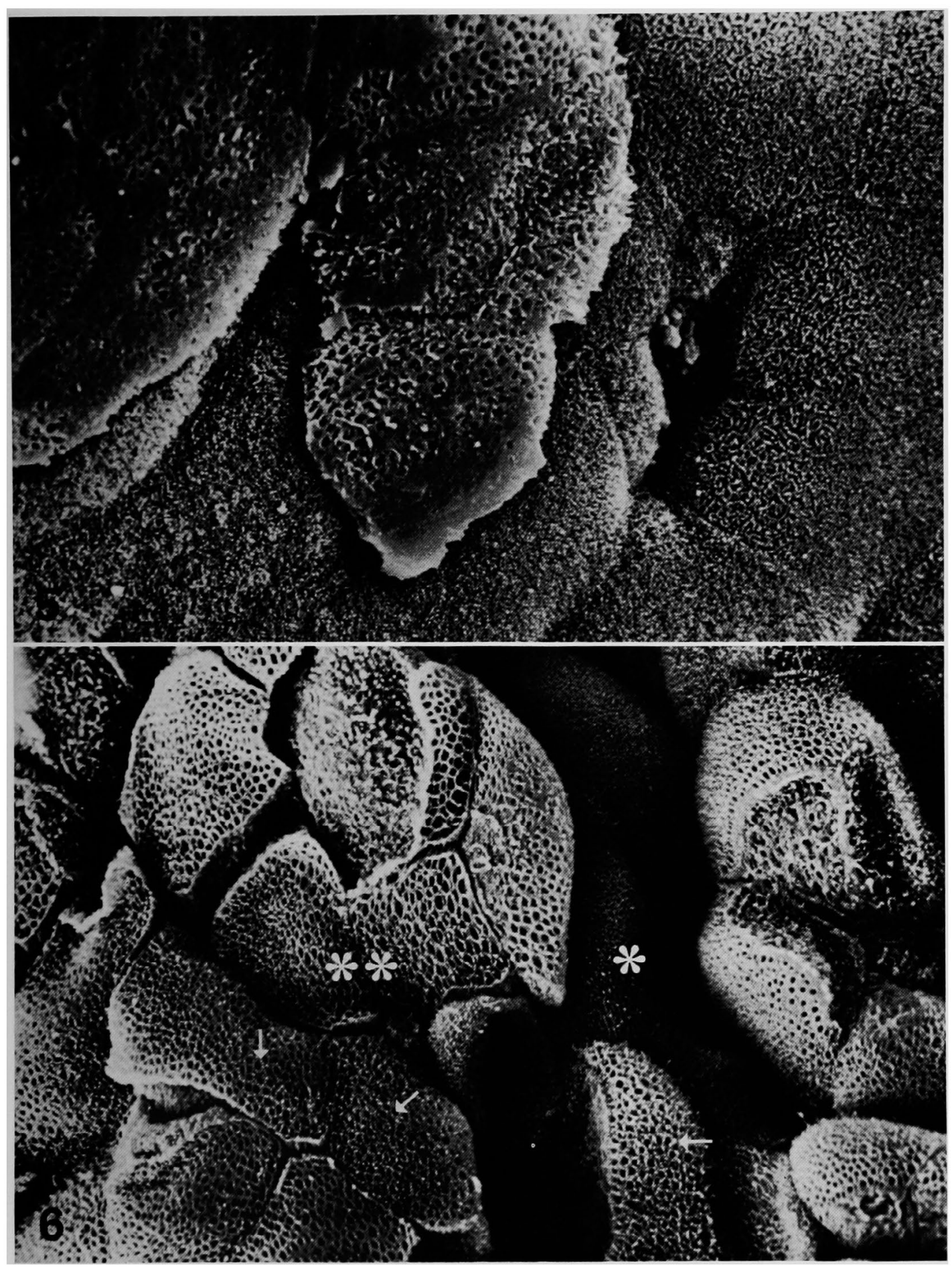




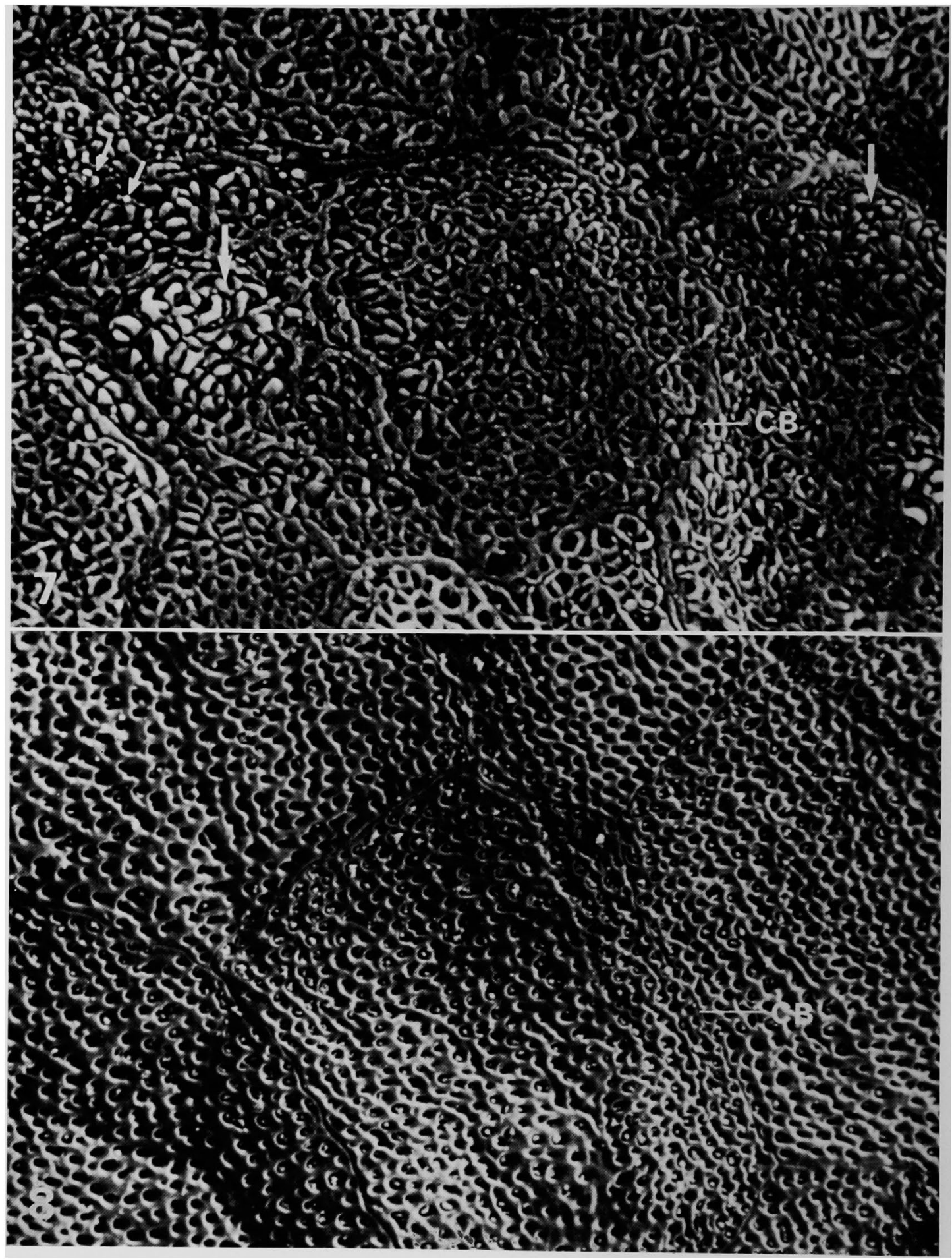



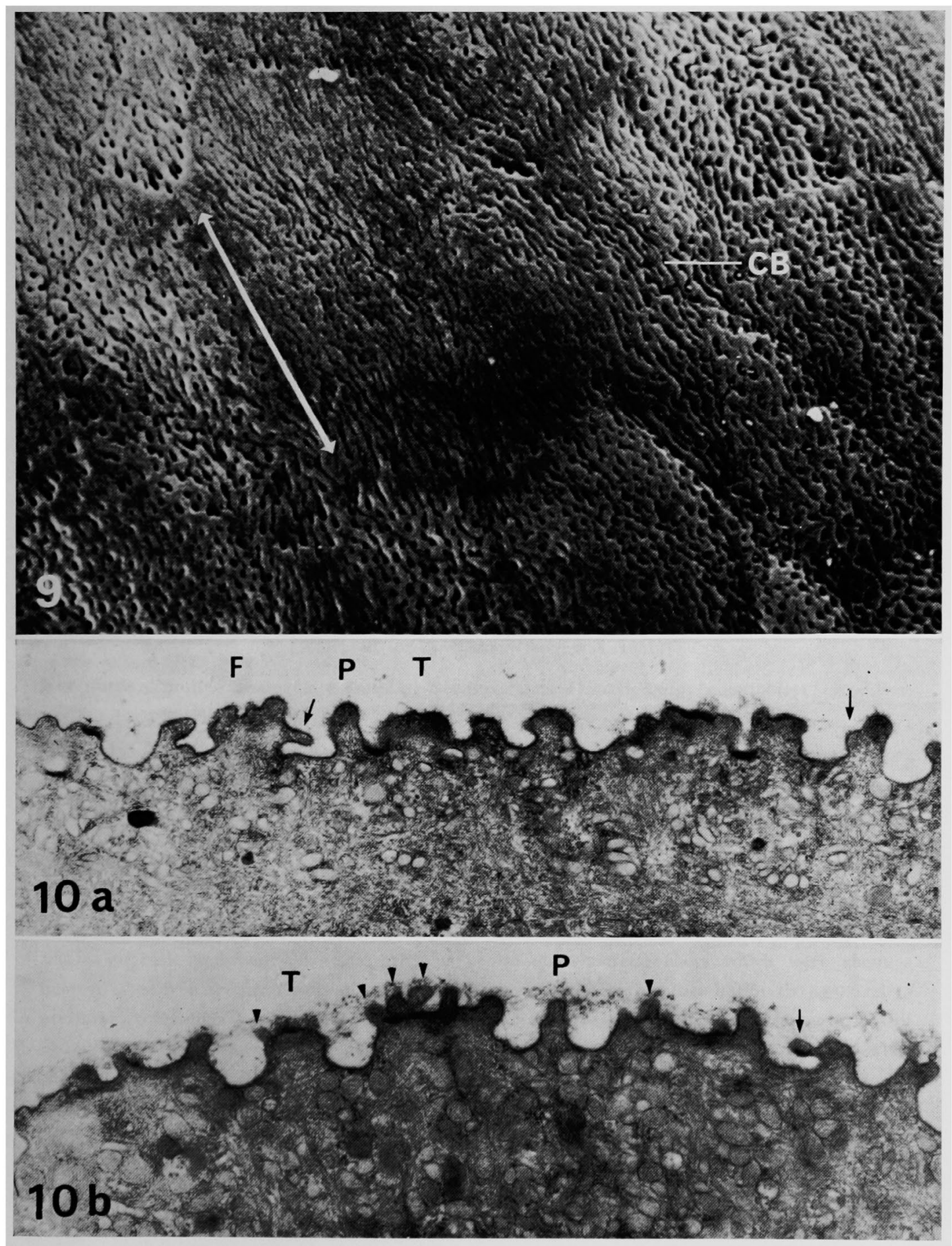


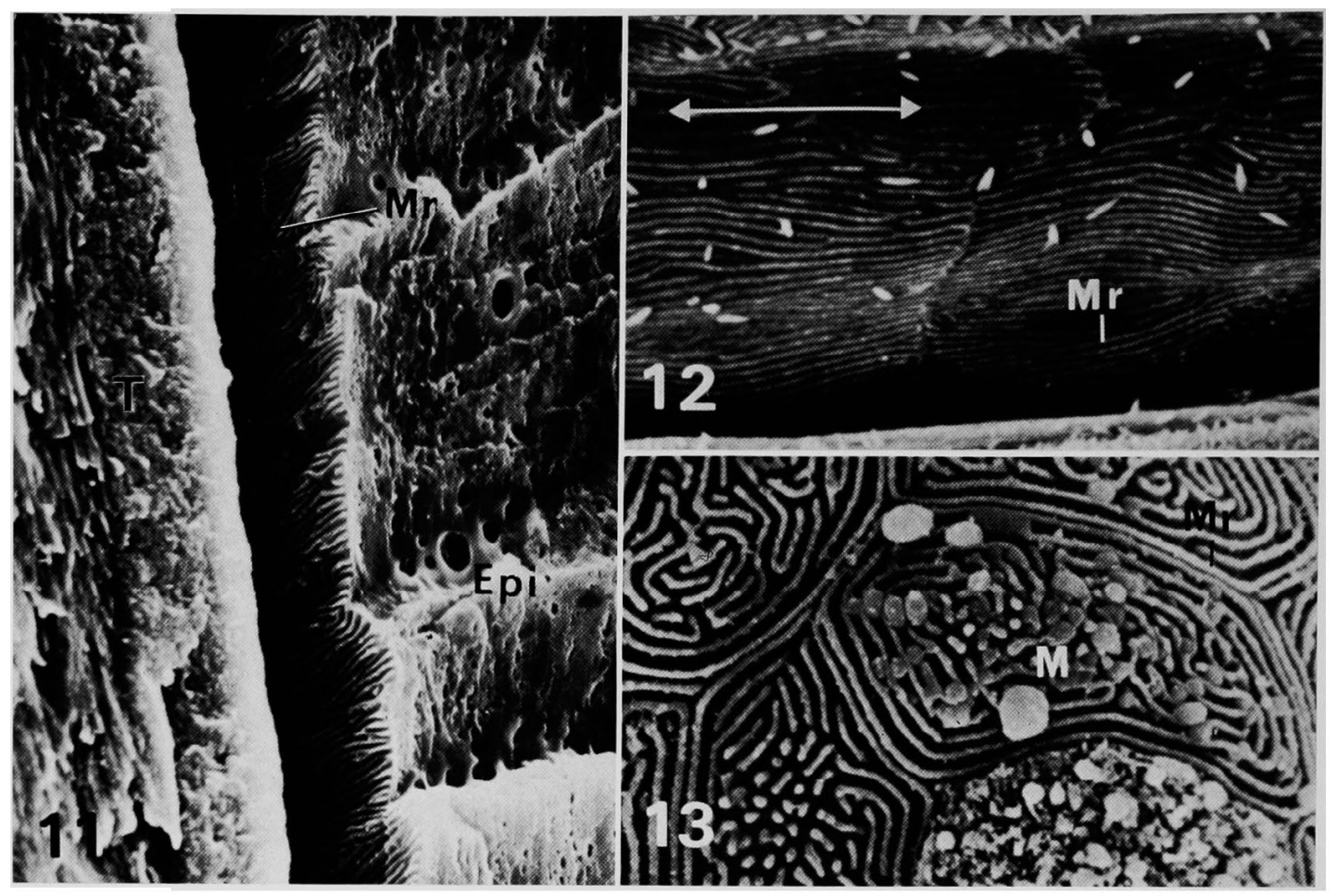

